\title{
Intertextualidade e compreensão leitora: ensino da leitura com apoio da tecnologia
}

\author{
Intertextuality and reading comprehension: teaching reading with the support of technology
}

Danielle Baretta ${ }^{1}$, Jésura Lopes Chaves $^{2}$

Mestranda em Linguística do Programa de Pós-graduação em Letras da Pontifícia Universidade Católica do Rio Grande do Sul (PUCRS).

E-mail: daniellebaretta@hotmail.com

Doutora em Linguística pela Pontifícia Universidade Católica do Rio Grande do Sul

(P-mail: jesuralc@gmail.com
RESUMO: 0 presente trabalho tem por objetivo demonstrar como a tecnologia pode apoiar o ensino, apresentando um objeto de aprendizagem voltado para o ensino de leitura. Nesse sentido, o objeto de aprendizagem, intitulado Fábulas Revisitadas, parte da concepção de que a compreensão leitora é fator central e essencial nas aulas de Língua Portuguesa e de que a escola é a responsável por promover a ampliação dos conhecimentos prévios do educando, tornando-o capaz de interpretar diferentes textos que circulam socialmente. Sendo assim, o objeto de aprendizagem em questão pretende desenvolver essa habilidade a partir da intertextualidade. Para tanto, apresenta blocos de atividades organizados em torno de cinco fábulas, nos quais o texto original é confrontado com outros textos que com ele dialogam. Espera-se, com isso, que os alunos reconheçam o papel dos conhecimentos prévios para uma efetiva compreensão leitora, bem como as pistas que permitem identificar o diálogo entre textos e os sentidos dele decorrentes.

PaLAVRAS-CHAVE: Compreensão leitora; Intertextualidade; Objeto de aprendizagem; Fábula

ABSTRACT: The aims of this work is to demonstrate how the technology can support teaching, presenting a learning object for teaching reading In this sense, the learning object entitled Fables Revisited, part of the idea that reading comprehension is central and essential factor in Portuguese classes and that the school is responsible for promoting the expansion of prior knowledge of the student, making it able to interpret different texts circulating socially. Therefore, the learning object in question intends to develop this skill from the intertextuality. It presents blocks of activities organized around five fables in which the original text is confronted with other texts with him dialogue. It is expected that students recognize the role of prior knowledge for effective reading comprehension, as well the clues identifying the dialogue between texts and the meanings from it resulting. KEYwoRDS: Reading comprehension; Intertextuality; Learning object; Fable 


\section{Introdução}

$\mathrm{R}$ esultados de provas oficiais que analisam o desempenho em leitura dos estudantes constatam que os índices alcançados pelos alunos brasileiros são insatisfatórios. Segundo relatório da Organização para Cooperação e Desenvolvimento Econômico ${ }^{1}$ (OCDE) de 2014, em 2012, o desempenho em leitura dos estudantes brasileiros piorou em relação a 2009. De acordo com dados do Programa Internacional de Avaliação de Alunos (Pisa), o país somou 410 pontos em leitura, dois a menos do que sua pontuação na última avaliação, sendo que a média dos países avaliados foi de 497 pontos. Com isso, o Brasil ficou na $55^{\text {a }}$ posição no ranking de leitura.

O relatório destaca, ainda, que quase metade $(49,2 \%)$ dos alunos brasileiros não alcança o nível 2 de desempenho na avaliação que tem o nível 6 como teto. Isso significa que eles não são capazes de reconhecer a ideia principal de um texto, realizar inferências elementares, entender as relações ou interpretar o significado dentro de uma parte delimitada do texto e estabelecer comparações ou conexões entre o texto e conhecimentos externos.

Esses resultados indicam a preocupante condição de compreensão leitora dos estudantes do Ensino Fundamental e Médio e revelam o quadro caótico em que se encontra o ensino de leitura nas escolas brasileiras, ainda dominado por práticas pedagógicas ultrapassadas.

Nas aulas de Língua Portuguesa, as atividades de leitura focalizam, na maioria das vezes, questões referentes ao conteúdo, com o objetivo de realizar associações com o mundo. 0 trabalho com os elementos linguísticos do texto é feito após as atividades de compreensão e delas desvinculado, caracterizando-se, via de regra, pelo ensino de normas gramaticais

$\overline{1}$ Disponível em: <http://educacao.uol.com.br/noticias>. Acesso em: 20 nov. 2015. classificatórias. Essa realidade indica a necessidade de se repensar as práticas de leitura na escola, revendo as estratégias adotadas.

Nesse sentido, as Tecnologias da Informação e da Comunicação (TICs) têm contribuído de maneira significativa para renovar o processo ensinoaprendizagem. Uma dessas contribuições é o desenvolvimento de objetos de aprendizagem, materiais digitais que permitem trabalhar conteúdos específicos de forma mais dinâmica, interativa e atraente. Atualmente, existem objetos de aprendizagem disponíveis na Internet para quase todas as disciplinas. No entanto, com relação à Língua Portuguesa, o acervo ainda é escasso se comparado com outras áreas do conhecimento, e os que existem focalizam, na maioria dos casos, o ensino e a prática de regras gramaticais. Poucos são os materiais que trabalham o ensino de leitura de forma consistente.

Desse modo, partindo da concepção de que a compreensão leitora é fator central e essencial nas aulas de Língua Portuguesa, o objetivo deste trabalho é apresentar um objeto de aprendizagem voltado para o ensino da leitura com foco na intertextualidade.

Para tanto, inicialmente, é exposta a concepção de leitura que dá suporte ao material elaborado. Em seguida, é realizada uma discussão sobre os conceitos de intertextualidade e de objetos de aprendizagem, destacando as características dessas ferramentas. Por fim, é apresentado e analisado o objeto de aprendizagem denominado Fábulas revisitadas. Na conclusão, são realizadas reflexões sobre o desenvolvimento de objetos de aprendizagem como uma alternativa para os problemas de compreensão evidenciados pelos estudantes brasileiros.

\section{Leitura numa perspectiva cognitiva}

A leitura consiste em uma atividade que requer fundamentalmente compreensão. Compreender um texto é construir sentidos, habilidade que 
pressupõe a ativação de diversos processos mentais. Para Smith (1999), a base da compreensão é a "previsão", entendida como "eliminação antecipada de alternativas improváveis", é o que possibilita ao leitor encontrar sentido naquilo que já sabe sobre o mundo. Trata-se de um exercício preciso e natural do cérebro humano. Aprende-se a ler através da leitura; por meio dessa atividade, aprimora-se a habilidade de prever e de construir hipóteses; aprimora-se a própria habilidade de aprender. O leitor deve ficar atento às pistas que o código escrito oferece e, assim, construir o sentido do texto. $\mathrm{O}$ autor ressalta que a compreensão é uma fonte de hipóteses que deve resultar na aprendizagem. Previsão e compreensão são essenciais para concretizar a aprendizagem.

$\mathrm{Na}$ mesma perspectiva teórica, Kleiman (1989) defende que a compreensão de um texto se caracteriza pelo uso do conhecimento prévio, pois o leitor utiliza na leitura o conhecimento adquirido ao longo da vida. O leitor constrói o sentido do texto pela interação de diversos níveis de conhecimento, como o linguístico, o textual e o enciclopédico. Sob essa ótica, considera a leitura um processo interativo. 0 conhecimento linguístico remete ao domínio da língua, implícito, não verbalizado, que possibilita aos usuários do português, por exemplo, comunicarem-se como nativos. Desempenha um papel central no processamento do texto, uma vez que, para que as palavras sejam percebidas, é necessário que a mente esteja ativa, ocupada em construir significados. A falta desse domínio torna impossível a compreensão. Já o conhecimento textual caracteriza-se por um conjunto de noções e de conceitos sobre o texto. 0 leitor precisa conhecer a estrutura do texto para que a compreensão se realize. Como ratifica a autora, quanto mais conhecimento textual o leitor tiver, quanto maior a sua exposição a todo tipo de texto, mais fácil será sua compreensão. Há ainda o conhecimento de mundo, ou enciclopédico, que pode ser adquirido formal ou informalmente, abrangendo desde o domínio específico de uma área até o conhecimento de fatos simples ou banais do cotidiano. A falta de familiaridade com determinado assunto implica incompreensão. Kleiman (1989) ressalta que, durante a leitura, é necessário que parte do conhecimento enciclopédico relevante à leitura de um texto seja ativada num nível ciente, passível de ser recuperada na memória.

Cita-se ainda o constructo teórico de Colomer e Camps (2002), que, tendo em vista a prática pedagógica da leitura, focalizam uma visão compreensiva do ensino de leitura na escola. Chamam a atenção, num primeiro momento, ao papel da língua escrita na organização da sociedade e ao modo como influenciou o entendimento e a valorização da leitura e da escrita ao longo do tempo. No século XX, especificamente, a redefinição dos objetivos do sistema educativo nas sociedades modernas relaciona-se ao título de igualdade de oportunidades no mercado de trabalho que a alfabetização adquiriu. Como decorrência desse novo direcionamento, defende-se uma concepção de língua escrita que estimule a formação de leitores críticos e criativos.

Ao tratarem da leitura, situam-na numa diretriz teórica que objetiva explicar como os seres humanos interpretam a realidade ou processam a informação recebida. Distinguem, então, o processamento ascendente, modelo vinculado a uma concepção mais tradicional de leitura, do descendente. 0 primeiro é um mecanismo que parte da análise do texto à compreensão do leitor; o segundo atua em sentido contrário, ou seja, da mente do leitor ao texto. Conforme as autoras, o que o leitor vê no texto e o que ele mesmo traz são dois subprocessos simultâneos e em estreita interdependência, visão que constitui os modelos interativos de leitura. Nesse sentido, o leitor é visto como um sujeito ativo, o que pressupõe uma visão dialética entre texto e leitor: de um lado, o leitor baseia-se em seus conhecimentos para interpretar um texto; por outro, esse novo significado permite-lhe criar, modificar ou incorporar novos conhecimentos em seus esquemas mentais. 
A respeito desses dois tipos básicos de processamento de informação, Kato (2007) acrescenta que podem servir de base para descrever tipos de leitores. Enquanto o processamento descendente (top-down) consiste numa abordagem não-linear que explora informações de forma dedutiva, cuja direção é da macro para microestrutura e da função para a forma, o processamento ascendente (bottom-up) faz uso linear e indutivo das informações linguísticas, centrando-se numa abordagem composicional, ou seja, o significado global é construído por meio de análise e síntese do significado das partes. Nesse sentido, o leitor que privilegia a forma descendente tende a apreender facilmente as ideias gerais e principais do texto, a ser fluente e veloz, porém fazendo uso excessivo de adivinhações, sem procurar confirmá-las com os dados do texto. Utiliza, sobretudo, seu conhecimento prévio em detrimento da informação efetivamente dada pelo texto. O leitor que se utiliza especialmente do processo ascendente, por sua vez, constrói o significado com base nos dados do texto, detém-se em detalhes como ortografia e faz pouca leitura nas entrelinhas. Tende a ser vagaroso e pouco fluente, apresentando dificuldade para sintetizar as ideias do texto; em contrapartida, não tira conclusões apressadas. Há ainda um terceiro tipo de leitor, considerado um leitor maduro, que usa, adequadamente, os dois processos de forma complementar. Para ele, a escolha desses processos é uma estratégia metacognitiva visto que exerce um controle consciente e ativo sobre seu comportamento. A formação desse tipo de leitor mostra-se, assim, uma alternativa bastante procedente para as práticas pedagógicas que contemplam a leitura.

\section{Intertextualidade: diálogo entre textos}

Para compreender intertextualidade, deve-se resgatar, num primeiro momento, a noção de dialogismo concebida por Mikhail Bakhtin. Nesse sentido, Barros e Fiorin (1999) elucidam que, na perspectiva do teórico russo, trata-se do princípio constitutivo da linguagem e da condição do sentido do discurso. 0 dialogismo pode ser desdobrado em dois aspectos: interação verbal entre o enunciador e o enunciatário do texto e intertextualidade no interior do discurso. Pode ainda ser considerado o diálogo entre muitos textos, que se instala no interior de cada texto e o define, caracterizado pelo cruzamento de vozes oriundas de práticas de linguagem socialmente diversificadas.

O termo intertextualidade, por sua vez, foi ressignificado por Julia Kristeva em 1969. Como explica Zani (2003), Bakhtin aborda o diálogo entre textos sob a perspectiva da literatura e da linguística; já Kristeva estende essa relação para outros universos, como o cinema e as artes plásticas. Num primeiro momento, foi objeto de estudo da literatura, que via nas citações textuais - inclusão de um texto em outro - um recurso de reprodução ou de transformação. Com o tempo, este artifício discursivo foi se estendendo para outras áreas.

Zani (2003) também distingue três tipos de ocorrência intertextual: citação, alusão e estilização. A citação ratifica ou altera o sentido do discurso, podendo se manifestar por outros meios, como teatro que cita as artes plásticas, cinema que recorre ao teatro ou artes plásticas que fazem referência à História do Arte. Esse processo mostra a relação discursiva explicitamente, sendo o discurso citado um elemento dentro de outro já existente. No que concerne à alusão, não há citação explícita, mas uma construção que reproduz a ideia central de algo já enunciado, aludindo a um discurso já conhecido do público em geral. Já a estilização consiste em uma forma de reproduzir os elementos de um discurso já existente, como uma reprodução estilística do conteúdo formal ou textual, com o propósito de reestilizá-lo.

Sant'Anna (2003), por sua vez, compara a estilização à paródia, outro tipo de intertextualidade, tomando por base o postulado de Tynianov e de 
Bakhtin. Para o primeiro, a estilização está próxima da paródia, mas este processo implica necessariamente discordância ou deslocamento entre os planos discursivos: a paródia de uma tragédia será uma comédia; a paródia de uma comédia pode ser uma tragédia. Para o segundo, a fusão de vozes, que é possível na estilização, não é possível na paródia, cujas vozes não são apenas distintas e emitidas de uma para outra, mas se colocam de forma antagônica.

Sant'Anna também elucida outro recurso intertextual: a paráfrase. Para-phrasis, que no grego significava continuidade ou repetição de uma sentença, remete à imitação ou à cópia. Trata-se de uma "reafirmação, em palavras diferentes, do mesmo sentido de uma obra escrita. Uma paráfrase pode ser uma afirmação geral da ideia de uma obra como esclarecimento de uma passagem difícil. Em geral, ela se aproxima do original em extensão" (SANT'ANNA, 2003, p. 17).

Não obstante esses conceitos serem originários da Literatura, é inegável sua relação com outras áreas. No âmbito da Linguística, a Linguística Textual apropriou-se desses conceitos para analisar o papel da intertextualidade no processo de compreensão do sentido de um texto. Para Koch e Travaglia (2014), a intertextualidade é um importante fator de coerência na medida em que, para o processamento cognitivo de um texto, recorre-se ao conhecimento prévio de outros textos.

Partindo das ideias de Barthes, importante crítico literário, Koch (1998) desdobra o conceito de intertextualidade em um sentido amplo e stricto sensu. No sentido amplo, a intertextualidade remete à interdiscursividade, sendo condição para que o discurso exista. Não há discurso homogêneo, dotado de uma única fonte do dizer. Ele sempre será construído sobre outros discursos. Desse modo, todo texto é um intertexto, uma vez que está atravessado por outras vozes, impregnado de valores e crenças.
A intertextualidade stricto sensu, por sua vez, se dá, segundo a autora, quando um texto retoma outro, conservando elementos do texto original, de modo a defender ou contestar as ideias nele presentes. Para elucidar esse conceito, Koch (2012) apresenta vários tipos de intertextualidade stricto sensu, classificando-a como: temática, estilística, intergenérica, explícita e implícita.

A intertextualidade temática refere-se ao diálogo entre textos da mesma área do saber, que partilham temas, conceitos e terminologias próprios. A intertextualidade estilística, por sua vez, ocorre quando o produtor do texto, com objetivos variados, repete, imita ou parodia certos estilos ou variedades linguísticas. Na intertextualidade intergenérica, um gênero exerce a função de outro. Já na intertextualidade explícita, como o próprio nome indica, há a citação da fonte do intertexto, enquanto na implícita, ocorre o contrário, ou seja, não há citação, cabendo ao leitor identificar as marcas do texto-fonte (KOCH, 2012).

Desse modo, ao explorar textos que estabeleçam diálogo com outros, o que implica conhecimento prévio desses discursos, pode-se desenvolver a compreensão leitora do educando. Nesse sentido, ele é estimulado a expandir seus conhecimentos linguísticos e a se apropriar de diferentes formas de leitura, ampliando também seu universo cultural. Cabe ao professor criar espaços que levem os alunos a interagir com as várias vozes existentes em cada texto, possibilitando novas construções de sentido.

\section{Objeto de aprendizagem: definições e características}

Numa sociedade em que a tecnologia está cada vez mais presente no cotidiano das pessoas, torna-se imprescindível sua presença também na escola, que não deve privar-se do acesso a novos recursos capazes de auxiliar na construção do conhecimento dos estudantes. 
Dentre esses recursos, que surgem a partir o uso das TICs, estão os chamados objetos de aprendizagem. Segundo Araújo (2013, p. 180), “os objetos surgiram em função da necessidade de se criarem novas estratégias de ensino-aprendizagem para a web e da necessidade de economia pessoal e de tempo na elaboração de materiais instrucionais". De acordo com a autora, apesar de a discussão sobre objetos de aprendizagem remontar a meados da década de 1990, ainda não há um consenso sobre a definição do termo. Para Leffa (2006), são tantas as definições quanto são os autores ou entidades envolvidas. Nesse sentido, o autor apresenta uma escala hierárquica, proposta por McGreal (MACGREAL, 2004 apud LEFFA, 2006), na qual são ordenadas definições desde as mais gerais até as mais específicas. Desse modo, um objeto de aprendizagem seria:

a) Qualquer coisa (DOWNES, 2003; FRIESEN, 2001; MORTIMER, 2002 apud LEFFA, 2006): segundo esta concepção, qualquer objeto pode ser considerado um objeto de aprendizagem, desde que usado na aprendizagem. Sendo assim, conforme exemplifica Leffa, um livro, um computador, uma vassoura ou até mesmo um penico, utilizado pelos pais para ensinar seus filhos a fazerem suas necessidades em local apropriado, seriam objetos de aprendizagem. Embora seja uma definição muito ampla, o autor a considera atraente do ponto de vista teórico já que é "o uso que se faz de um objeto que o torna ou não um objeto de aprendizagem" (LEFFA, 2006, p. 5).

b) Qualquer coisa digital (WILEY, 2000): Wiley define objeto de aprendizagem como "qualquer recurso digital que pode ser reusado como suporte para a aprendizagem" (WILEY, 2000, p. 7). Temos aqui, portanto, uma definição mais restritiva. Essa restrição, segundo Leffa, se deve a características próprias dos arquivos digitais, tais como a facilidade de edição, adaptação e incorporação a outros arquivos, que não permitiriam que objetos que não fossem digitais pudessem ser considerados objetos de aprendizagem. Leffa destaca que, embora mais específica, para ser útil, esta definição "precisa levar em conta os objetivos para os quais foram elaborados os arquivos digitais" (LEFFA, 2006, p. 6).

c) Qualquer coisa com objetivo educacional (QUINN \& HOBBS, 2000 apud LEFFA, 2006): nessa definição não há distinção entre digital e nãodigital. A principal diferença com relação à primeira definição é o fato de os objetos serem tratados como blocos de conteúdo educacional que podem ser reagrupados em blocos maiores para compor uma aula, uma disciplina ou um curso (LEFFA, 2006).

d) Qualquer coisa digital com objetivo educacional (ALBERTA LEARNING, 2002; CISCO SYSTEMS, 2001; KOPER, 2001 apud LEFFA, 2006): essa é a definição predominante de objeto de aprendizagem. Nesta perspectiva, qualquer arquivo digital, seja ele um texto, uma imagem ou um vídeo, poderia ser um objeto de aprendizagem se utilizado no ensino. Leffa salienta que, embora mais aceita, muitos autores teriam restrições a essa definição por conta do termo "qualquer" que não considera a ideia de blocos ou unidades menores de aprendizagem.

Nesse contexto de (in)definições, Leffa apresenta, ainda, a proposta do Programa de Extensão da Universidade de Wisconsin, que destaca algumas características desses objetos que contribuem para definição mais clara e precisa do termo. Segundo esse programa, um objeto de aprendizagem é uma

pequena unidade eletrônica de informação educacional que se caracteriza por ser flexível, reusável, customizável, interoperável, recuperável, capaz de facilitar a aprendizagem baseada nas competências e aumentar o valor do conteúdo (University of Wisconsin-Extension apud LEFFA, 2006, p. 7).

Esta definição, na qual se ampara o presente trabalho, remete aos conceitos de granularidade, reusabilidade, interoperabilidade e recuperabilidade, 
características que constituem os objetos de aprendizagem na sua estrutura e operacionalidade.

A granularidade refere-se ao tamanho do objeto, podendo ser entendida como "a menor porção do objeto com todas as informações essenciais de um tema” (BRAGA, DOTTA, PIMENTEL e STRANSKY, 2012, p. 91-92). Segundo Leffa (2006, p. 8) um objeto de aprendizagem é "um módulo que pode se ajustar a outros de várias maneiras, formando um conjunto homogêneo e funcional". Já a reusabilidade, remete à possibilidade de um objeto de aprendizagem ser utilizado em contextos de aprendizagem diferentes daquele para o qual foi criado. A interoperabilidade, por sua vez, diz respeito à capacidade de adaptação do objeto de aprendizagem, que deve apresentar a possibilidade de operar através de uma variedade de hardwares, sistemas operacionais e browsers (MENDES; SOUSA e CAREGNATO, 2004). Por fim, a recuperabilidade consiste na facilidade de acesso ao objeto de aprendizagem, por meio da pesquisa de metadados ${ }^{2}$ indexados ao objeto.

Além dessas características, há também uma classificação proposta por Sheperd (2000) que considera os conteúdos desses materiais e não seus elementos estruturais. Para o autor, os objetos de aprendizagem podem ser:

a) Integrados: mini-tutoriais, mini-estudo de casos, simulações etc.

b) Informativos: visões gerais, sumários, descrições, definições, exemplos de trabalhos, artigos etc.

c) Práticos: jogos, simulações, exercícios de prática e treinamento, exercícios de revisão, testes e avaliações.

A esses aspectos, é preciso somar-se uma das principais características dos objetos de aprendizagem: a possibilidade de favorecer o processo ensinoaprendizagem. Esses materiais oferecem aos professores uma nova forma de

2 Metadados podem ser definidos como "dados que descrevem os dados", ou seja, são informações
úteis para identificar, localizar, compreender e gerenciar os dados. Disponível: <https://metadados uteis para identificar, localizar, compre
ibge.gov.br>. Acesso em 25 mar. 2016. planejar suas aulas à medida que permitem diminuir o custo com o tempo de elaboração de materiais, aproveitando-se os já existentes. O professor, tendo à sua disposição uma grande quantidade de objetos, dos mais diferentes tipos, poderá planejar suas aulas fazendo uso deles, conseguindo maior flexibilidade para se adaptar ao ritmo e ao interesse dos alunos, mantendo seus objetivos de ensino (NUNES, 2012).

No entanto, para que favoreçam a aprendizagem, os objetos, independentemente de seu formato, devem possuir um embasamento teórico e um paradigma pedagógico para sua concepção (MACHADO, LONGHI e BEHAR, 2013).

Desse modo, para o elaboração do objeto de aprendizagem que será apresentado mais adiante, procurou-se unir a flexibilidade e dinamicidade das TICs a uma concepção teórica que possibilitasse a qualificação do ensino da leitura.

\section{Fábulas revisitadas ${ }^{3}$ : objeto de aprendizagem para trabalhar a intertextualidade}

O objeto de aprendizagem apresentado neste artigo tem como tema a intertextualidade. Seu objetivo é desenvolver a habilidade de reconhecer as pistas que permitem identificar o diálogo entre textos bem como os sentidos dele decorrentes. Para tanto, elegeu-se a fábula como fio condutor das atividades propostas por ser um gênero constantemente revisitado por escritores e que, na contemporaneidade, tem sido utilizado por diferentes mídias como elemento de composição de novas produções.

${ }^{3}$ O objeto de aprendizagem Fábulas Revisitadas está disponibilizado, até o presente momento, apenas em CD-ROM. Há previsão de, futuramente, incluí-lo no Banco Internacional de Objetos Educacionais. Disponível em: <http://objetoseducacionais2.mec.gov.br>. 
Para o desenvolvimento do objeto utilizou-se a ferramenta de autoria Edilim $^{4}$, software de código livre que permite a criação de atividades interativas em diferentes formatos como, por exemplo, caça-palavras, quebra-cabeças, forca, múltipla escolha, esquemas, entre outros.

Figura 1 - Tela de abertura do objeto de aprendizagem Fábulas Revisitadas

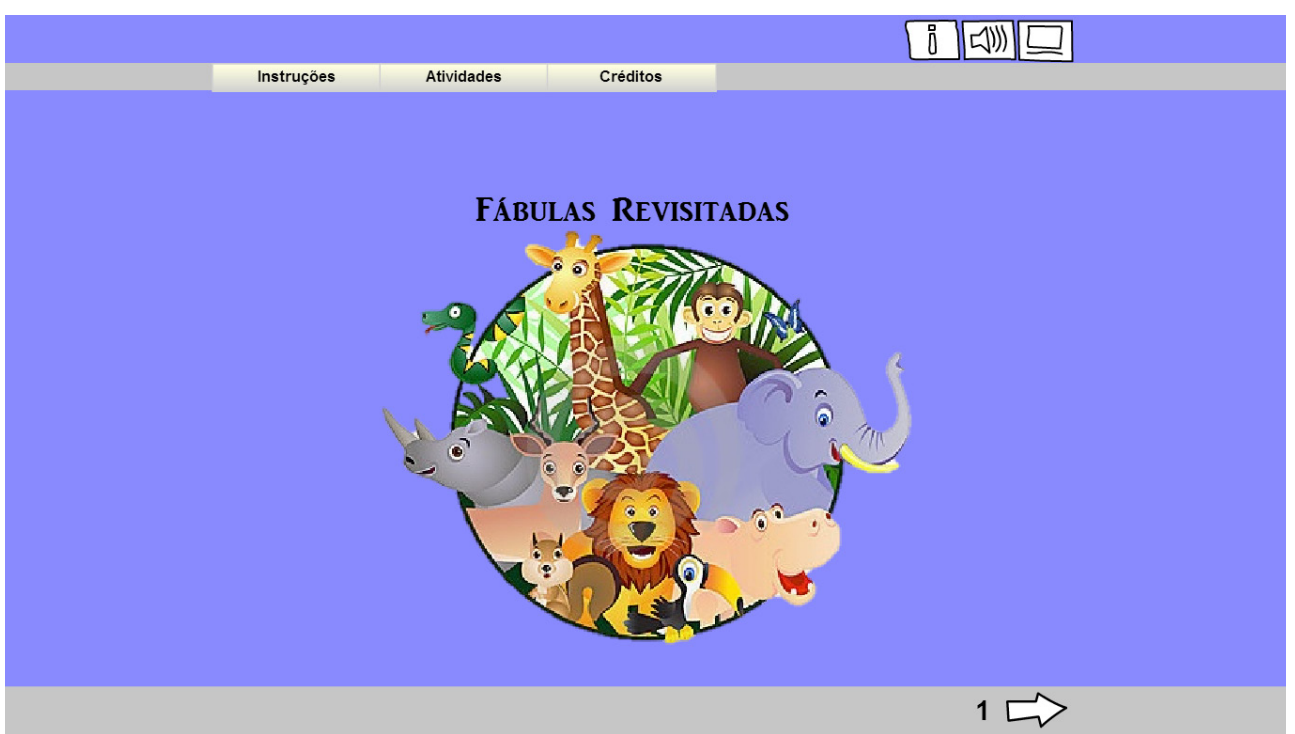

Fonte: As autoras.

O objeto de aprendizagem, destinado a alunos do Ensino Fundamental, consiste em um trabalho de leitura realizado a partir de cinco fábulas. Desse modo, são apresentados blocos de atividades, nos quais o texto original é confrontado com outros que com ele dialogam. Esses textos apresentam 4 Desenvolvido por Fran Macías, é composto por um editor de atividades (Edilim), um visualizador (LIM)
e um arquivo em formato XML (livro) que pode ser exportado para o formato HTML, o que permite a
inserção em um site na Internet. Disponível em: <http://www.educalim.com>. gêneros variados tais como: fábulas, contos, tiras, anúncios publicitários, músicas, cartuns, histórias em quadrinhos etc. e estabelecem relação com o texto-fonte por meio de paródias, paráfrases, alusões, citações ou recriações.

Figura 2 - Tela sumário do objeto de aprendizagem Fábulas Revisitadas

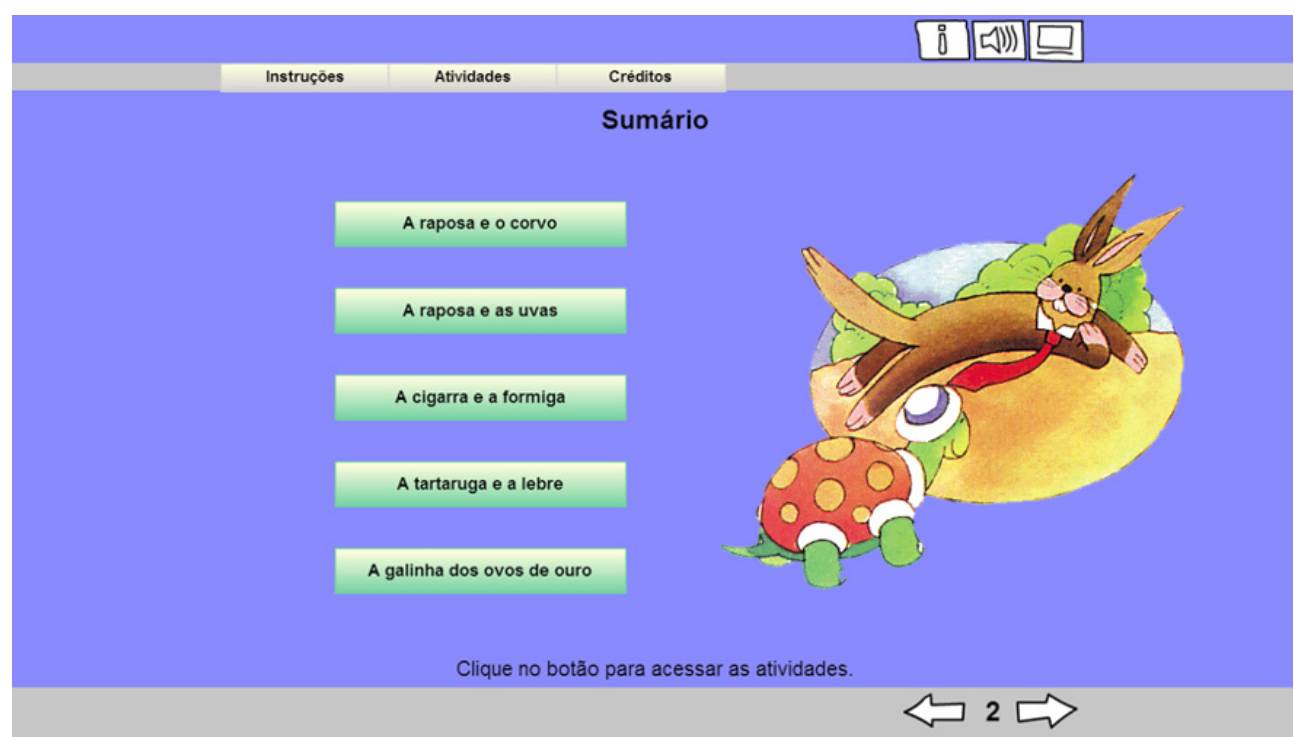

Fonte: As autoras.

As atividades propostas utilizam alguns dos diferentes formatos disponibilizados pela ferramenta de geração de conteúdo e dispõem de recursos de interação, tais como setas de navegação, sistema de feedback e relatório de desempenho. As Figuras 3, 4 e 5, a seguir, ilustram esses recursos. 
Figura 3 - Tela de feedback positivo. Seta de navegação em destaque

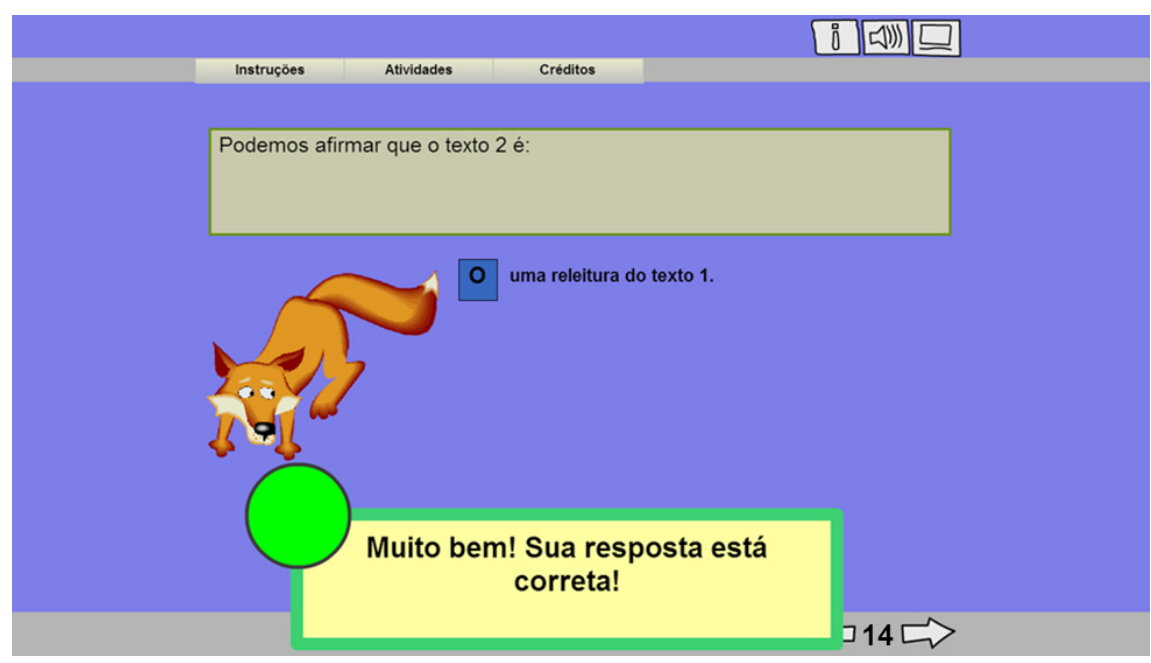

Fonte: As autoras

Figura 4 - Tela de feedback negativo

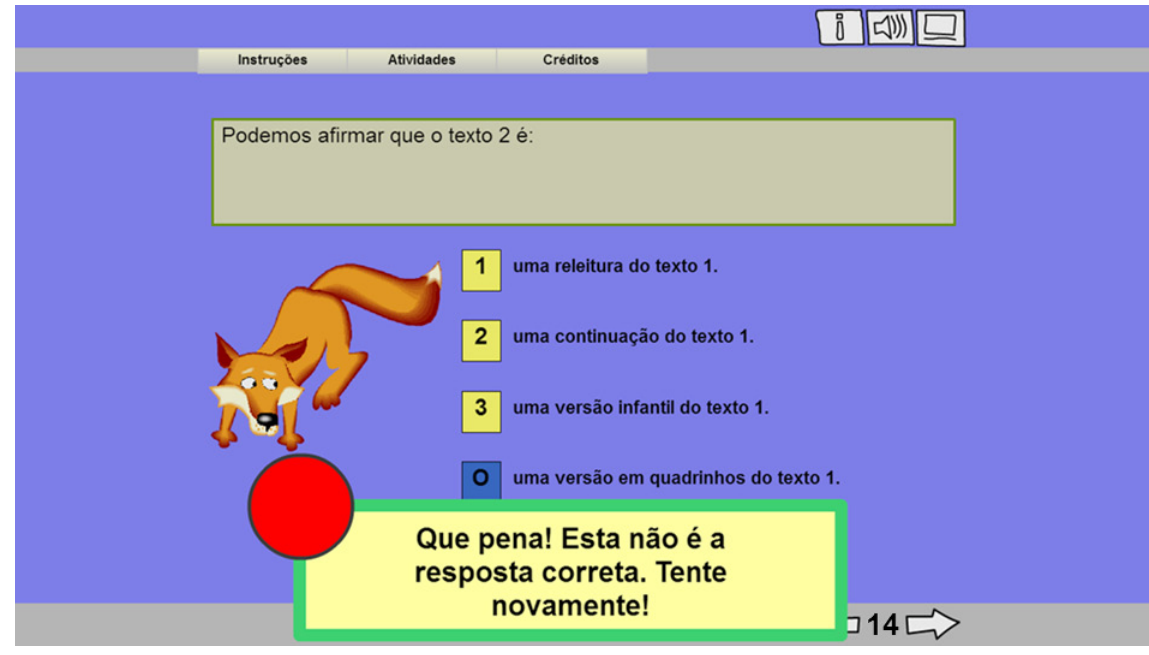

Fonte: As autoras.
Figura 5 - Tela do relatório de desempenho

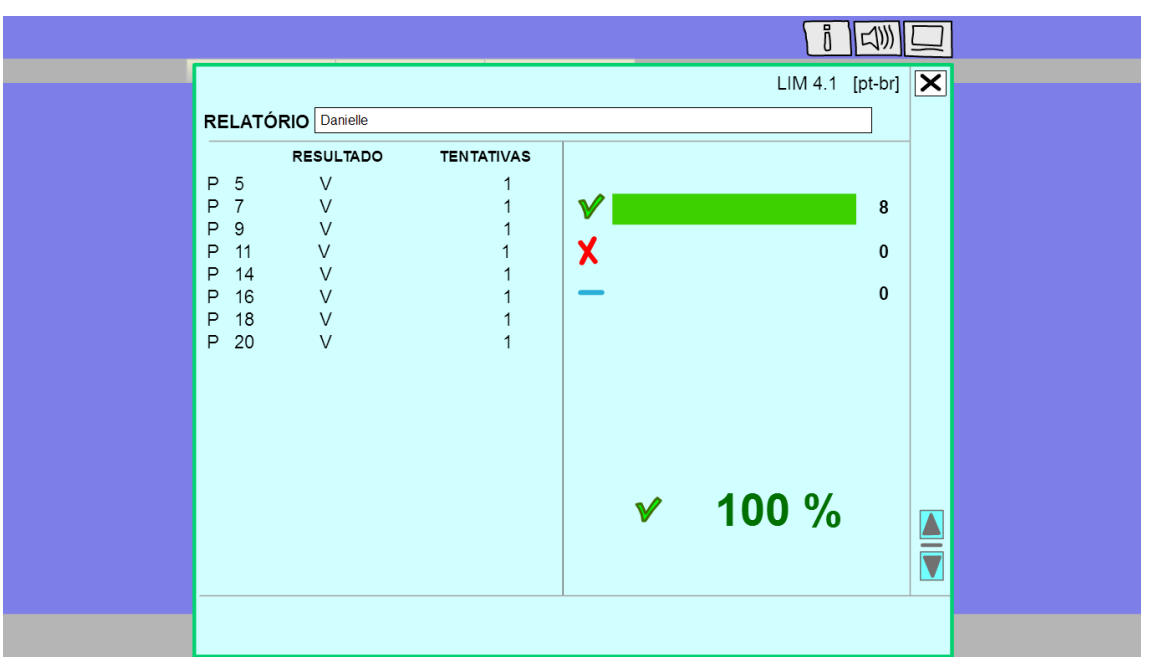

Fonte: As autoras.

Com relação às características do objeto de aprendizagem, há a presença da granularidade, uma vez que faz um recorte de uma temática mais abrangente: a intertextualidade no processo de compreensão leitora, podendo, facilmente, ajustar-se a outros materiais, compondo, por exemplo, um módulo sobre leitura. Além disso, ao apresentar instruções, feedbacks e relatórios de desempenho pode ser utilizado não só no apoio às aulas presenciais, como também em cursos a distância, garantindo, assim, sua reusabilidade. Ao ser elaborado a partir de um software que permite que os arquivos sejam exportados para o formato HTML, o objeto de aprendizagem é capaz de operar em diferentes sistemas operacionais e browsers, apresentado, portanto, características de interoperabilidade. A recuperabilidade, por sua vez, está prevista na medida em que se pretende disponibilizar o material em um repositório de objetos de aprendizagem com grande número de acessos: o Banco Internacional de Objetos Educacionais. 
No que diz respeito à concepção pedagógica, para a elaboração dos blocos de atividades, decidiu-se não apresentar informações teóricas acerca da intertextualidade. Trata-se, portanto, de um objeto de aprendizagem prático, segundo classificação proposta por Sheperd (2006), uma vez que o objetivo é levar o aluno a identificar o processo de intertextualidade por meio da leitura e comparação de textos que dialogam entre si, sem, necessariamente, apresentar conceitos e nomenclaturas relacionados a esse tema.

Dessa forma, nas atividades, o texto-fonte sempre é o primeiro a ser apresentado com o intuito de instrumentalizar o aluno com o conhecimento necessário para estabelecer as relações propostas na comparação entre os textos. Para tanto, antes da leitura dos intertextos, são apresentadas atividades de compreensão leitora acerca do texto-fonte que possam auxiliar o reconhecimento da intertextualidade e dos sentidos criados no diálogo entre os textos analisados. Cabe mencionar que, nessas atividades, evitou-se apresentar perguntas que exigissem a mera localização de informações explícitas nos textos e que, portanto, não garantiriam a compreensão. Sendo assim, as atividades foram elaboradas de modo a estimular o aluno a relacionar seus conhecimentos prévios e as pistas linguísticas presentes no texto para realizar as inferências necessárias a uma compreensão mais aprofundada do texto, que servirá de suporte para um posterior trabalho com a intertextualidade.

Além disso, ao responder corretamente, o aluno é encaminhado a uma tela, denominada Para refletir (Fig. 6), que contém um texto que estimula a reflexão sobre as estratégias utilizadas e sobre os elementos considerados na construção dos sentidos do texto. 0 objetivo é tornar conscientes os percursos cognitivos utilizados no processamento da leitura, transformando, desse modo, estratégias cognitivas em estratégias metacognitivas (KATO, 2007).
Figura 6 - Tela do tópico Para refletir

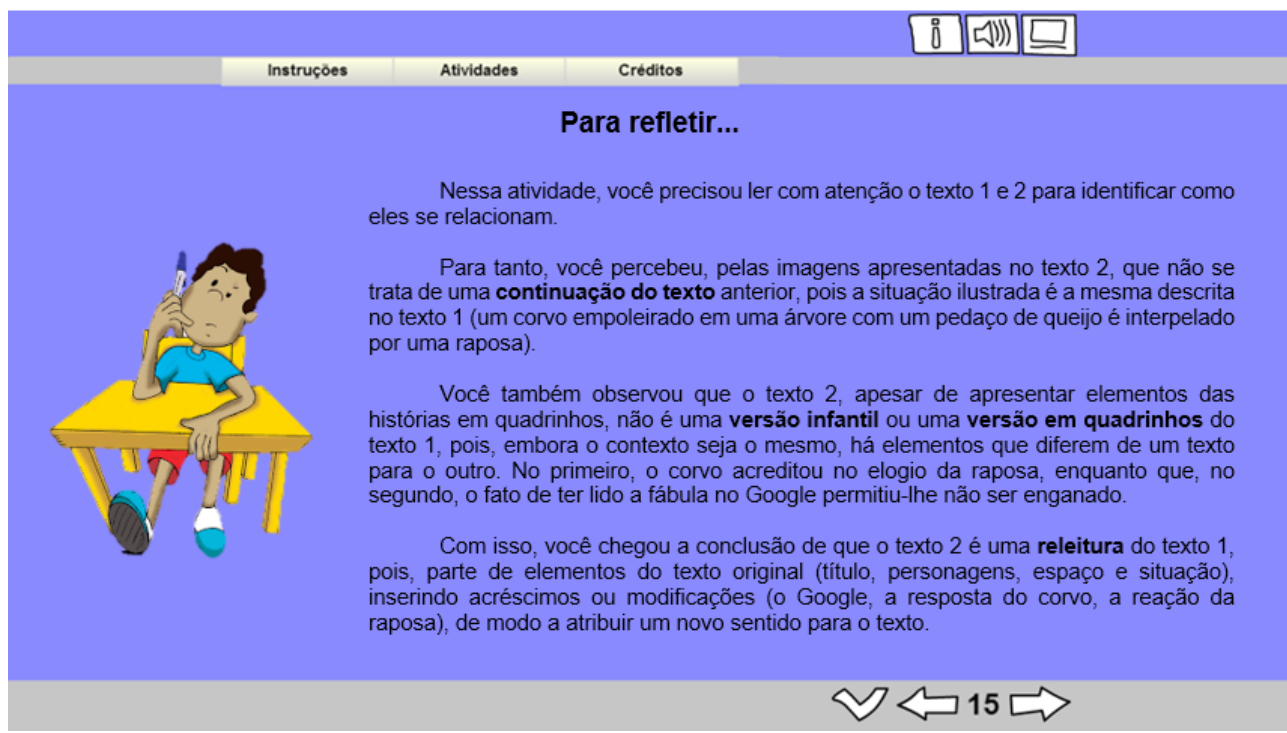

Fonte: As autoras.

A seguir, serão analisadas algumas das atividades desenvolvidas com o intuito de ilustrar de que forma a intertextualidade e a compreensão leitora são trabalhadas no objeto de aprendizagem.

As atividades apresentadas referem-se ao diálogo estabelecido entre dois textos: a fábula $A$ raposa e o corvo, de Esopo, e um cartum, também intitulado $A$ raposa e o corvo, de autor desconhecido, que recria a situação da fábula nos dias atuais.

Na primeira tela desse bloco de atividades (Fig. 7), é apresentado o texto-fonte com o qual o diálogo intertextual será estabelecido. As atividades seguintes orientam o aluno no processo de compreensão leitora do texto. 
Figura 7 - Tela para leitura da fábula A raposa e o corvo

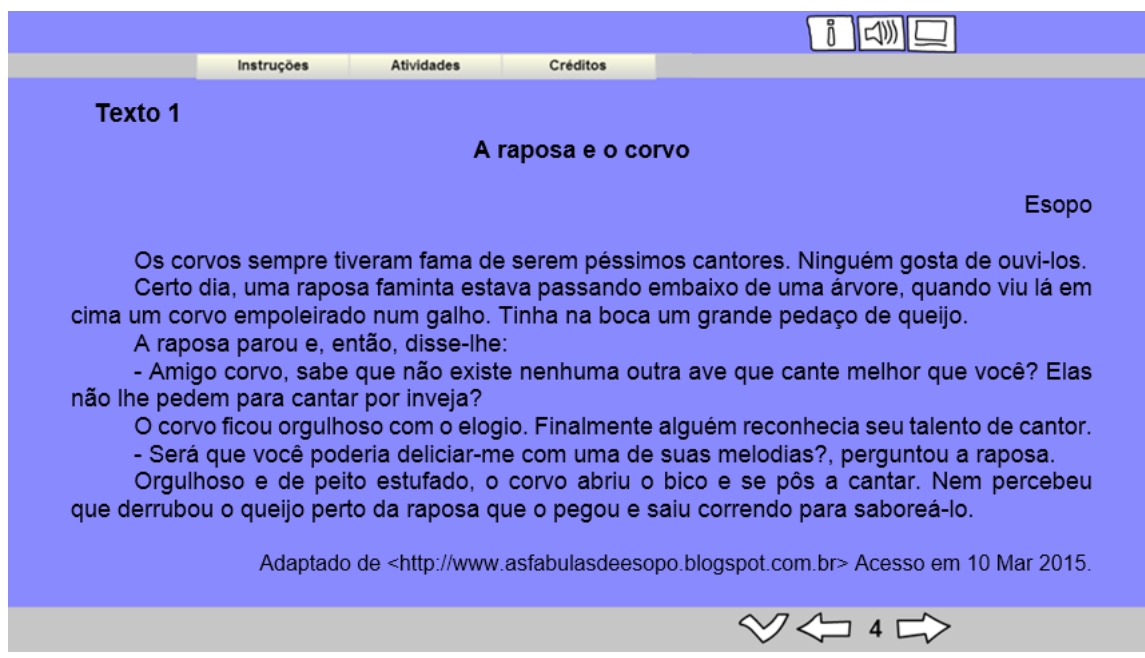

Fonte: As autoras.

A primeira questão (Fig. 8) leva o aluno a perceber as relações de sentido que as partes do texto estabelecem entre si. Uma das características de um bom texto é a coerência, que pode ser observada, entre outros aspectos, pela ausência de contradição interna (CHAROLLES, 1998). Para identificar a frase que antecipa que a raposa não estava sendo sincera ao elogiar o corvo, o aluno deverá perceber que, no texto, a expressão "Os corvos sempre tiveram fama de serem péssimos cantores. Ninguém gosta de ouvi-los" aponta para uma incoerência entre o que afirma o narrador e a fala da raposa. Desse modo, para manter a ausência de contradição interna, o aluno deverá concluir que este trecho demonstra que a raposa não está falando o que realmente pensa.

Com a atividade, o aluno é instigado a buscar na materialidade do texto, as pistas que amparam a realização de inferências. Essa habilidade é muito importante e deve ser trabalhada em sala de aula, pois como destacam Castro e Pereira (2004), no processamento da leitura, o leitor não pode apenas considerar seu conhecimento prévio sem basear-se nos elementos linguísticos do texto, pois correria o risco de construir um sentido equivocado, que não encontra amparo no texto.

Figura 8 - Tela questão 1 da atividade $A$ raposa e o corvo

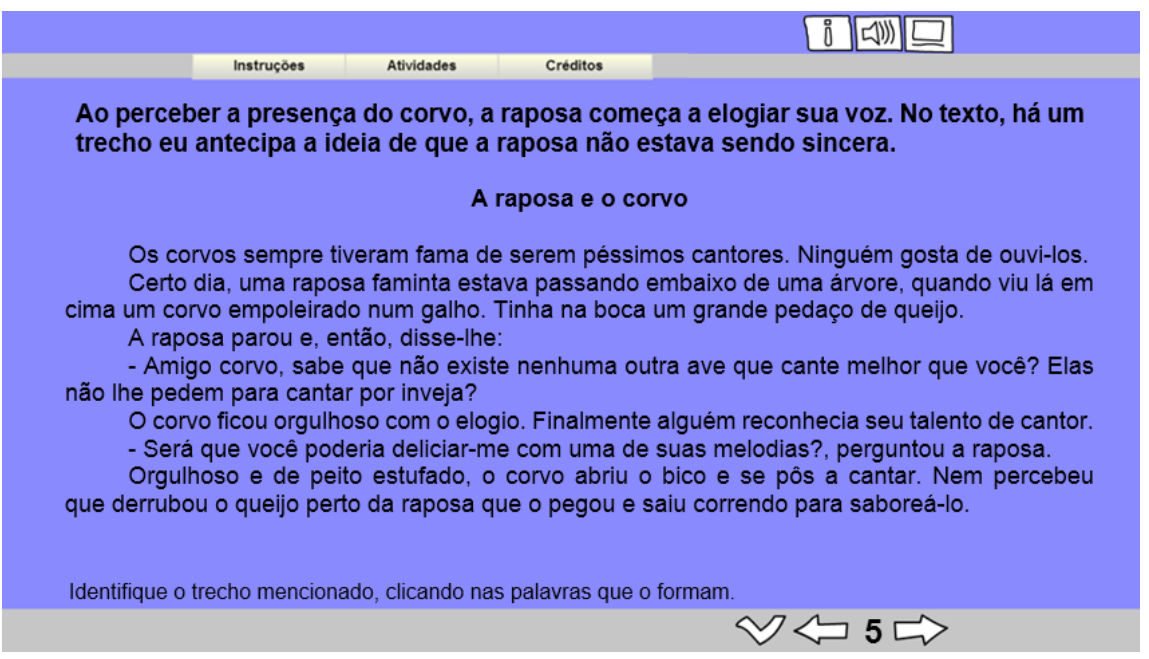

Fonte: As autoras.

Na segunda questão (Fig. 9), os alunos devem realizar inferências que expliquem o comportamento da personagem. Desse modo, ao associar o conhecimento de que, nas fábulas, as raposas geralmente são apresentadas como animais mentirosos e traiçoeiros a pistas linguísticas como o queijo que estava no bico do corvo e o adjetivo faminta para referir-se à raposa, o aluno poderá reconstruir sentidos não expressos formalmente, mas que são peças essenciais para a compreensão global do texto. A habilidade de realizar inferências, relacionando os conhecimentos prévios às pistas do texto é fundamental para a formação de um leitor proficiente. 
Figura 9 - Tela questão 2 da atividade $A$ raposa e o corvo

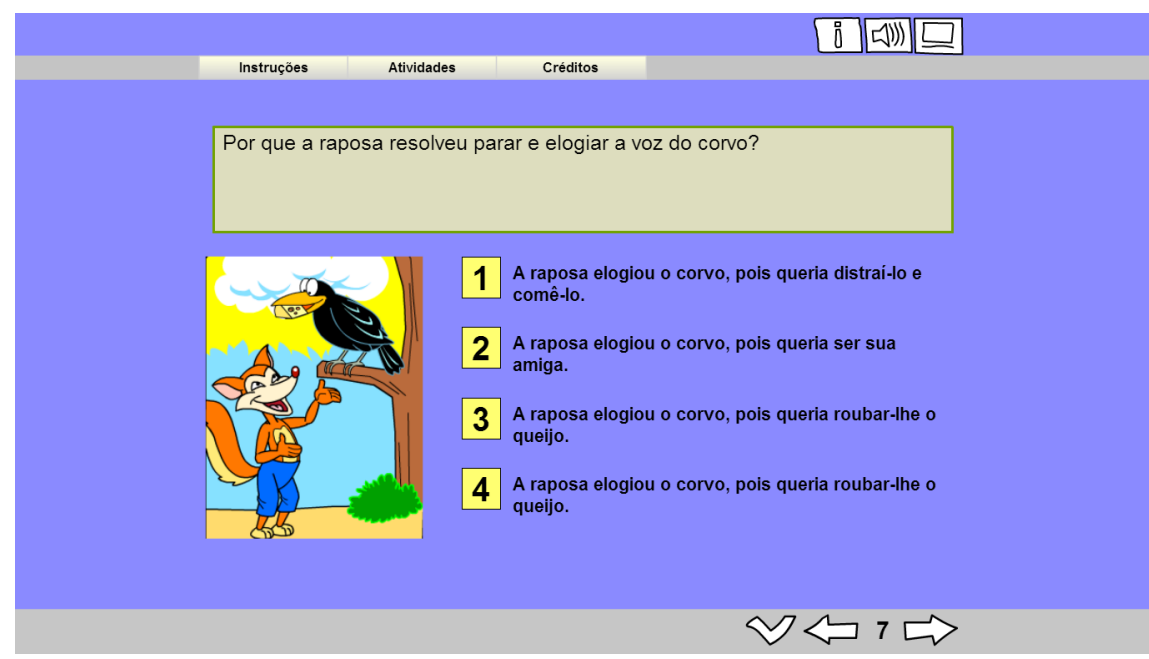

Fonte: As autoras.

Para Nelly Novaes Coelho, a fábula é uma narrativa breve, tal como apólogo e a parábola, que visa a dar uma lição aos homens. Seus personagens são animais falantes que se comportam como humanos. Nela, as situações narradas denunciam sempre erros de comportamento, que resultam na exploração do homem pelo homem" (cf. COELHO, 2008, p. 136-137). Sendo assim, na terceira questão (Fig. 10), os alunos devem relacionar as características humanas representadas no texto aos personagens da fábula. Para responder à questão, os alunos deverão mobilizar seus conhecimentos prévios sobre o gênero textual. Assim, espera-se a compreensão de que o corvo representa a vaidade humana e, por isso, se deixa enganar pela raposa. Esta, em contrapartida, se apresenta como alguém malicioso, que tenta aproveitar-se dos demais. Desse modo, a questão requer a inferência de informações subentendidas no texto.
Figura 10 - Tela questão 3 da atividade A raposa e o corvo

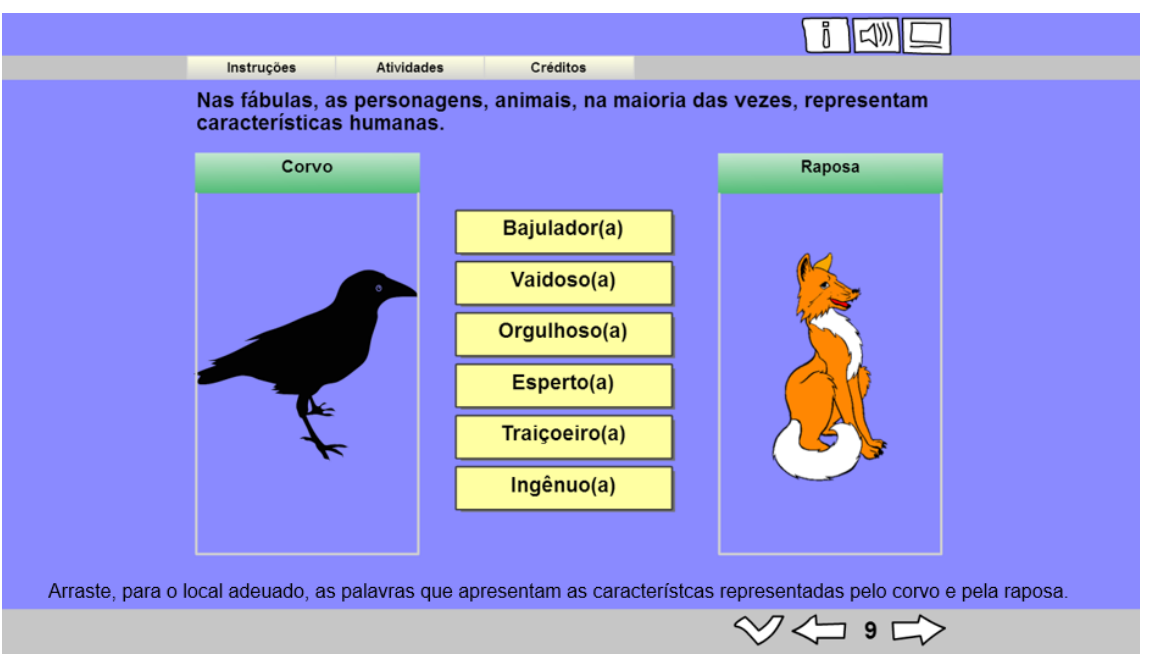

Fonte: As autoras.

A última questão sobre o texto-fonte (Fig. 11) solicita que o aluno reconheça a moral da história. As fábulas são narrativas curtas que trazem um ensinamento, expresso por meio da moral que, normalmente, aparece no final do texto. Desse modo, ela nos remete à intencionalidade do texto. Portanto, para identificá-la, o aluno precisa compreender o sentido global do texto. Para que isso ocorra, ele deverá recorrer aos elementos evidenciados nas questões anteriores para compreender o texto em sua macroestrutura.

Após completar as atividades relacionadas ao texto-fonte, o aluno entra em contato com o intertexto (Fig. 12). As atividades que o seguem procuram trabalhar a relação entre os dois textos. 
Figura 11 - Tela questão 4 da atividade A raposa e o corvo

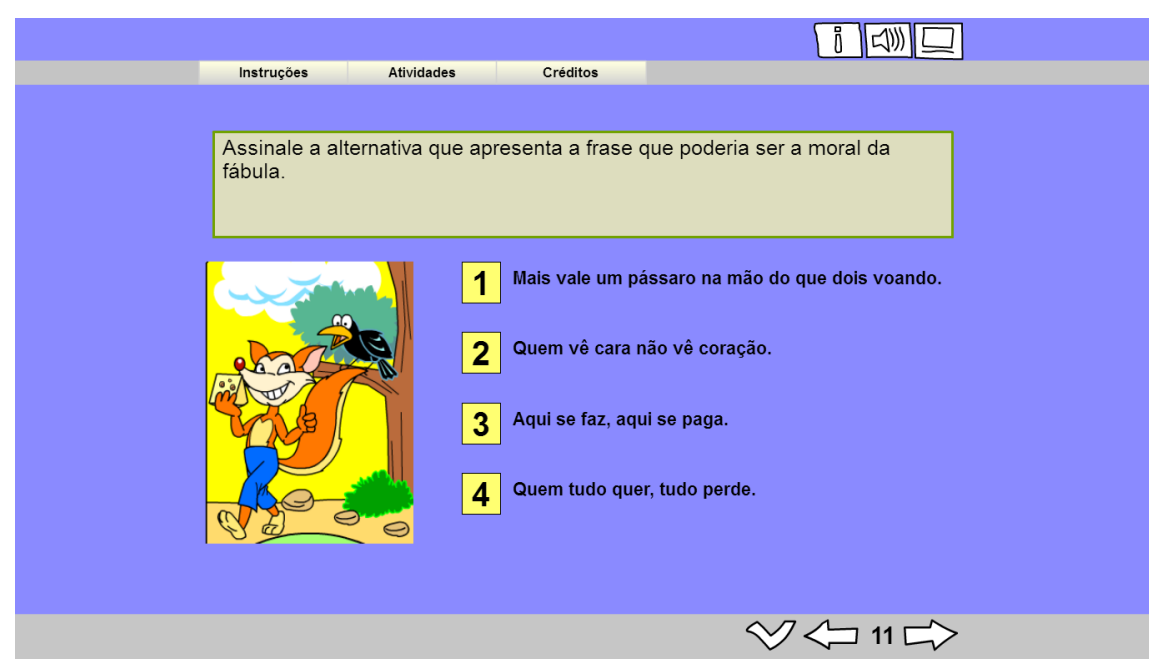

Fonte: As autoras.

Figura 12 - Tela para leitura do cartum A raposa e o corvo

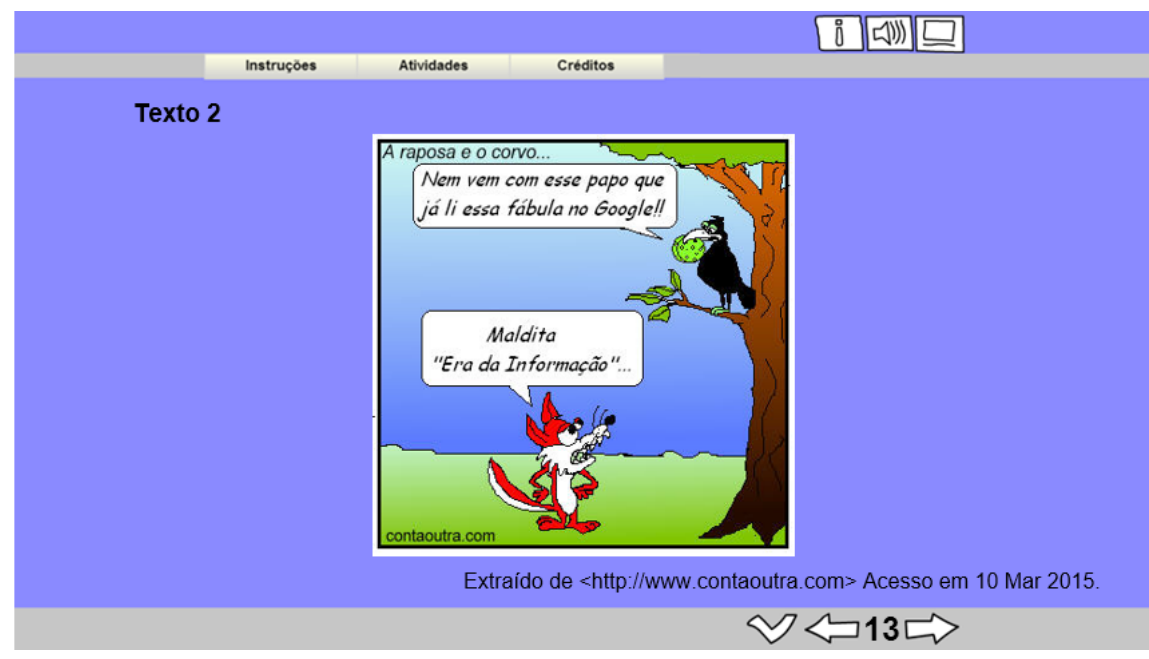

Fonte: As autoras,
A primeira questão referente ao texto 2 (Fig. 13) trabalha com o conceito de intertextualidade intergenérica. Desse modo, ao confrontar os dois textos, o aluno é instigado a perceber não só a presença de um gênero em outro, como também o diálogo estabelecido entre eles. Para isso, deverá apoiar-se nas pistas do texto (título, reprodução visual do lugar e da situação presentes na narrativa) para identificar os elementos que retomam o texto original, confrontando-os com as pistas que o subvertem (o Google, a recusa do corvo, a indignação da raposa), de modo a reconhecer que não se trata de uma simples transposição do texto-fonte para um gênero diferente, mas de uma releitura construída a partir da interação entre esses elementos.

Figura 13 - Tela da questão 5 da atividade $A$ raposa e o corvo

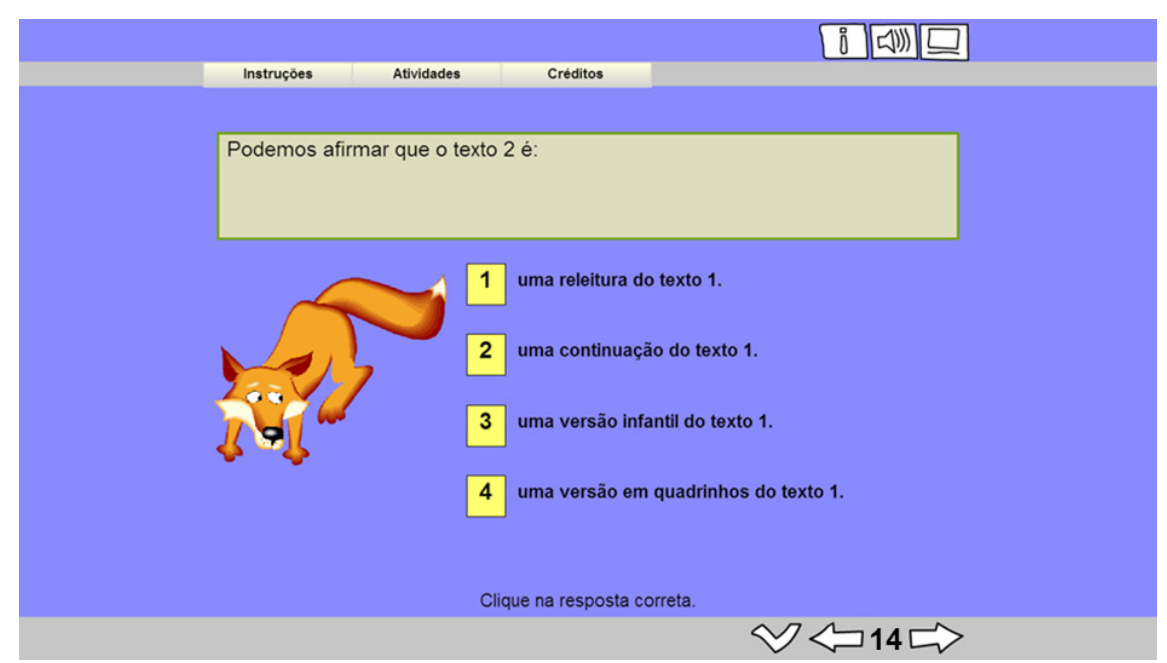

Fonte: As autoras,

A questão 6 (Fig. 14) solicita que o estudante escolha a alternativa que indica o ponto em comum entre o texto-fonte e o intertexto. A intertextualidade, nesse caso, se constitui de modo a remeter a passagens do 
texto original. Assim, o texto-fonte está presente não só na linguagem nãoverbal que reconstrói a cena apresentada na fábula, como também na fala do corvo que reporta a um momento específico da narrativa. Conhecer o texto original é, portanto, condição imprescindível para a construção do sentido.

Figura 14 - Tela da questão 6 da atividade A raposa e o corvo

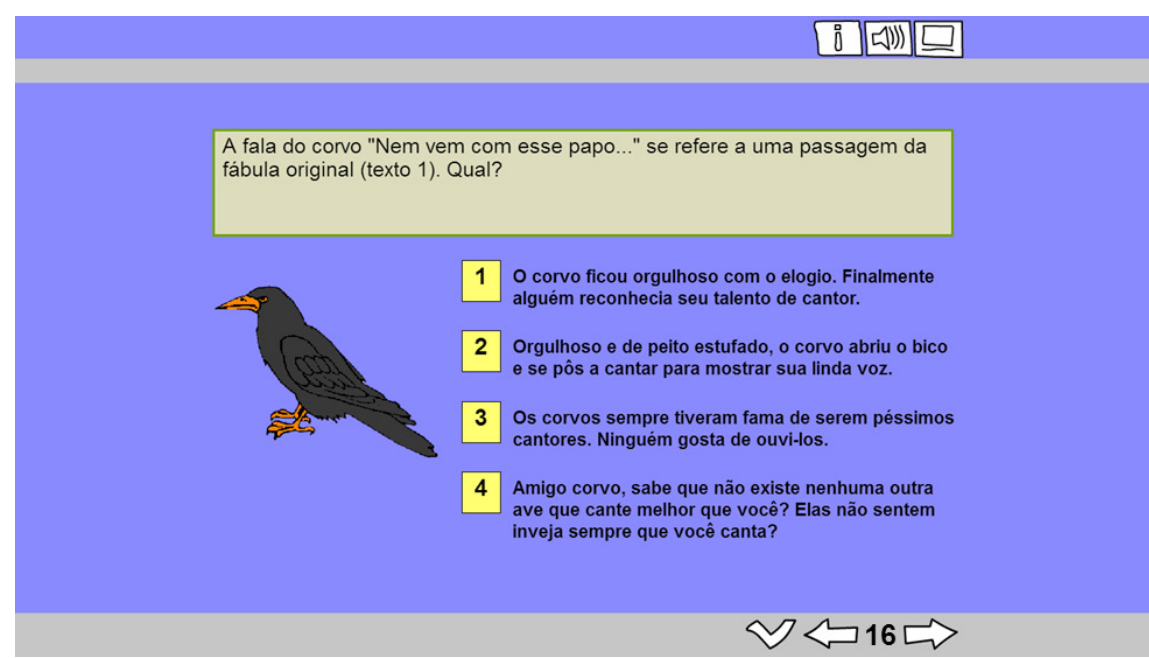

Fonte: As autoras.

A atividade proposta, ao confrontar o texto-fonte e o intertexto, pretende estimular o aluno a identificar essas relações. Para tanto, alguns conhecimentos deverão ser ativados no processo de compreensão como, por exemplo, o conhecimento do sentido polissêmico da palavra "papo" que, nesse contexto, se refere a uma conversa informal, remetendo ao diálogo entre a raposa e o corvo presente no texto original e resgatado no intertexto.

$\mathrm{O}$ autor, ao produzir o texto remetendo a passagens do texto original, espera que o leitor não só identifique essa passagem como também perceba o efeito de sentido provocado pelo deslocamento do enunciado original.

Desse modo, após identificar a presença do texto-fonte proposta na atividade anterior, nessa questão (Fig. 15), o aluno é levado a reconhecer que, no intertexto, o autor recupera o enredo original para subvertê-lo ao inserir um elemento que altera o desfecho da narrativa. Assim, o leitor precisa identificar que a existência da Internet, que possibilitou ao corvo pesquisar a fábula no Google e conhecer o final da história, mudou completamente o rumo da história e, consequentemente o sentido do texto.

Figura 15 - Tela da questão 7 da atividade $A$ raposa e o corvo

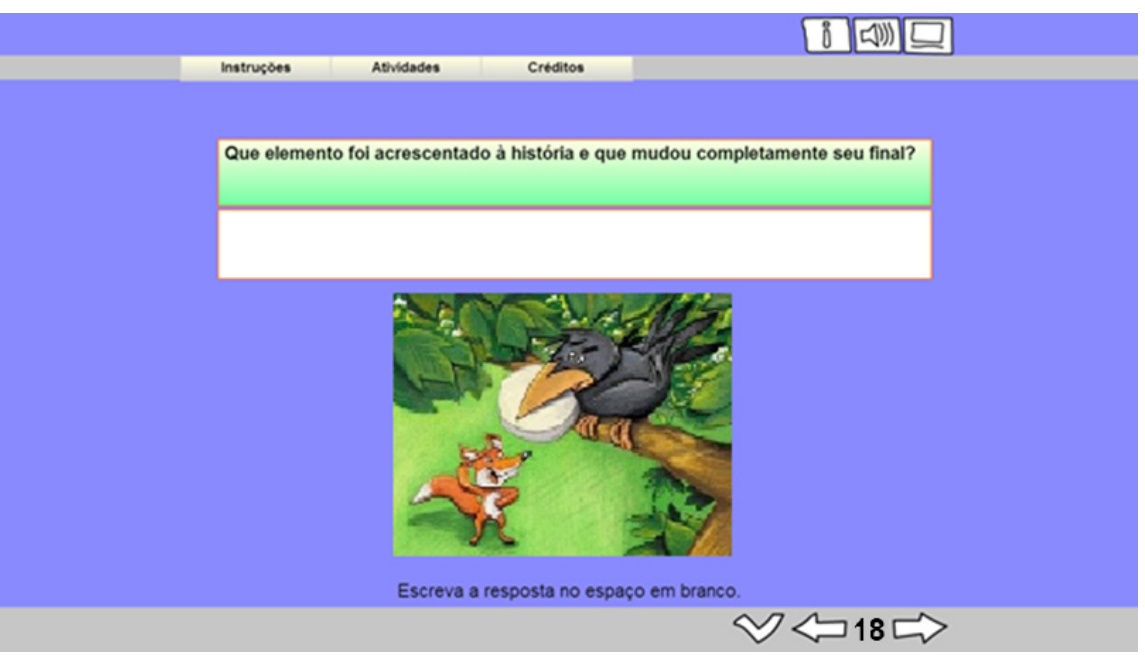

Fonte: As autoras.

Segundo Koch e Elias, para o processo de compreensão, mesmo nos casos em que a intertextualidade se caracteriza por uma paráfrase próxima do texto original, é preciso considerar que "a retomada de textos em outros propicia a construção de novos sentidos, uma vez que são inseridos em 
uma outra situação de comunicação, com outras configurações e objetivos" (KOCH e ELIAS, 2011, p. 85-86).

Sendo assim, a última questão desse bloco de atividades (Fig. 16) completa o processo de compreensão ao estimular o leitor a confrontar a intenção do autor da fábula original com a intenção proposta pelo intertexto. Como dito anteriormente, temos aqui um caso de intertextualidade intergenérica, na qual um gênero exerce a função de outro: um cartum (texto 2) com características de uma fábula (texto 1). Desse modo, ao assinalar a alternativa que poderia configurar uma possível moral para a história, o leitor é levado a recriar, no contexto do novo gênero, elementos do gênero visitante. Para tanto, deverá basear-se em seus conhecimentos prévios sobre o papel da moral na composição das fábulas e usar as pistas linguísticas presentes no intertexto ("Google", "Era da informação") para identificar as alterações de sentido decorrentes da mudança de contexto.

Figura 16 - Tela da questão 8 da atividade A raposa e o corvo

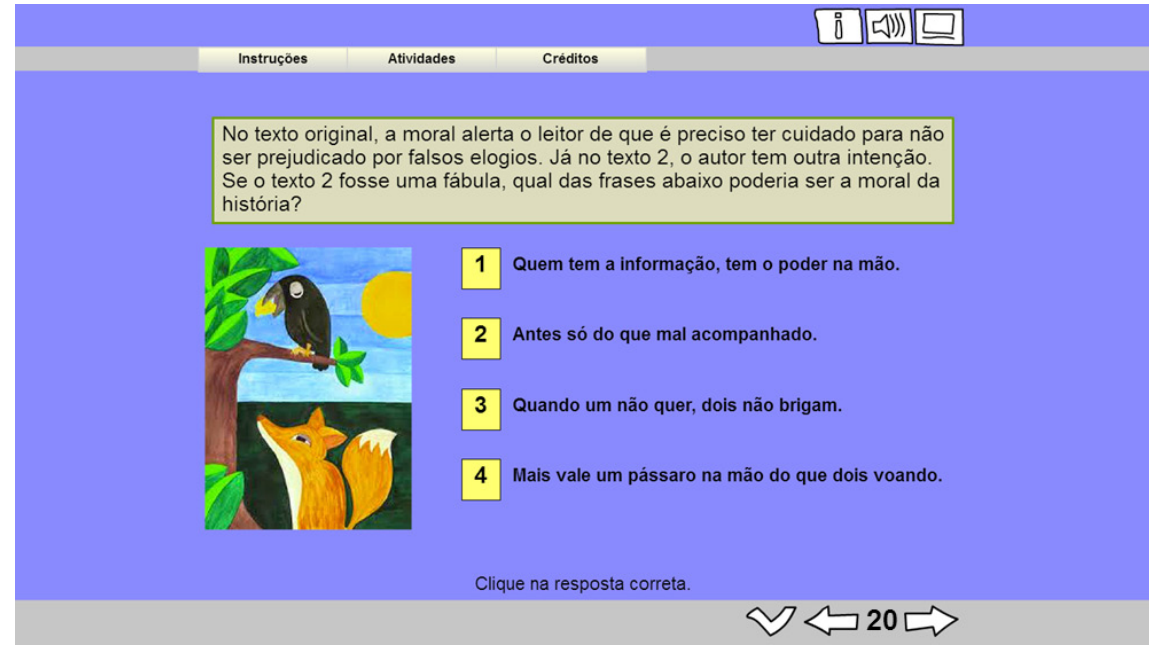

Fonte: As autoras.
As atividades aqui descritas demonstram a preocupação já mencionada em propor um material pedagógico que apresente um trabalho consistente voltado ao ensino da leitura, aliando o interesse dos alunos pelas TICs a uma concepção teórica sólida e a um conteúdo relevante.

\section{Conclusão}

Neste trabalho, pretendeu-se demonstrar como a tecnologia pode apoiar o ensino, apresentando um objeto de aprendizagem voltado para o desenvolvimento da compreensão leitora, com foco na intertextualidade.

Para tanto, foram apresentados os pressupostos teóricos que embasaram a elaboração do objeto de aprendizagem, destacando conceitos referentes a leitura numa perspectiva cognitiva e a práticas de intertextualidade. Além disso, buscou-se levantar as principais características comumente atribuídas a um objeto de aprendizagem.

Nesse percurso, apresentou-se, também, uma explicação acerca do modo como esses fundamentos se mostravam presentes no objeto desenvolvido, por meio da análise de algumas de suas atividades. Com isso, pretendeuse demonstrar que, embora apresentem muitas possibilidades e recursos, os materiais tecnológicos, quaisquer que sejam, só serão significativos e produtivos no processo ensino-aprendizagem se fundamentados em uma concepção teórica sólida e consistente.

Há muito ainda a ser feito para aproveitar as potencialidades das TICs no ensino. $\mathrm{O}$ objeto de aprendizagem apresentado, somando-se a outras iniciativas já existentes, consiste num esforço nesse sentido. No contexto do ensino de Língua Portuguesa, o material elaborado, ao trabalhar com a intertextualidade possibilita promover a ampliação dos conhecimentos prévios do educando, desenvolvendo a habilidade de reconhecer as pistas que permitem identificar o diálogo entre textos bem como os sentidos dele 
decorrentes, habilidade que poderá ser empregada em outros contextos, tornando os alunos capazes de interpretar diferentes textos que circulam socialmente, requisito imprescindível numa sociedade letrada e com fácil acesso à informação.

\section{Referências}

ARAÚJO, Nukácia Meyre Silva. A avaliação de objetos de aprendizagem para o ensino de língua portuguesa: análise de aspectos tecnológicos ou didático-pedagógicos? In: ARAÚJO, Júlio; ARAÚJO, Nukácia Meyre Silva (Orgs.). Ead em tela: docência, ensino e ferramentas digitais. Campinas: Pontes, 2013. p. 179-207.

BARROS, Diana Luz Pessoa de; FIORIN, José Luiz (Orgs.). Dialogismo, polifonia, intertextualidade. São Paulo: Edusp, 1999.

BRAGA, Juliana; DOTTA, Silvia; PIMENTEL, Edson; STRANSKY, Beatriz. Desafios para o desenvolvimento de objetos de aprendizagem reutilizáveis e de qualidade. In: WORKSHOP DE DESAFIOS DA COMPUTAÇÃO APLICADA À EDUCAÇÃO, 2012, Curitiba. Anais do ... Curitiba, 2012. p. 90-99.

CASTRO, Joselaine Sebem de; PEREIRA, Vera Wannmacher. Leitor e texto: a preditibilidade faz a interação. Calidoscópio, v. 2, n. 1, 2004

CHAROLLES, Michel. Introdução aos problemas de coerência dos textos: abordagem teórica e estudo das práticas pedagógicas. In: GALVES, Charlotte; ORLANDI, Eni Puccinelli; OTONI, Paulo (Orgs.). O texto: leitura e escrita. Campinas: Pontes, 1998. p. 39-85.

COELHO, Nelly Novaes. $O$ conto de fadas: símbolos, mitos, arquétipos. São Paulo: Paulinas, 2008.

COLOMER, Teresa; CAMPS, Anna. Ensinar a ler, ensinar a compreender. Trad. Fátima Murad. Porto Alegre: Artmed, 2002.

KATO, Mary Aizava. O aprendizado da leitura. 6. ed. São Paulo: Martins Fontes, 2007. KLEIMAN, Ângela. Aspectos cognitivos da leitura. Campinas, SP: Pontes, 1989. KOCH, Ingedore Villaça. O texto e a construção dos sentidos. São Paulo: Contexto, 1998. KOCH, Ingedore Villaça; ELIAS, Vanda Maria. Ler e compreender os sentidos do texto. São Paulo: Contexto, 2011.
KOCH, Ingedore Villaça; BENTES, Anna Cristina; CAVALCANTE, Márcia Magalhães. Intertextualidade: diálogos possíveis. São Paulo: Cortez, 2012.

KOCH, Ingedore Villaça; TRAVAGLIA, Luiz Carlos. A coerência textual. São Paulo: Contexto, 2014

LEFFA, Vilson J. Nem tudo que balança cai: objetos de aprendizagem no ensino de línguas. Polifonia, Cuiabá, v. 12, n. 2, p. 15-45, 2006.

MACHADO, Leticia Rocha; LONGHI, Magalí; BEHAR, Patrícia Alejandra. Domínio tecnológico. In: BEHAR, Patrícia A. (Org.). Competências em Educação a distância. Porto Alegre: Penso, 2013. p. 56-80.

NUNES, César (2012). Objetos de aprendizagem a serviço do professor. Disponível em: <http://ptce-iff.blogspot.com.br>. Acesso em: 12 mar. 2016.

SANT’ANNA, Affonso Romano. Paródia, paráfrase e Cia. São Paulo: Ática, 2003.

SHEPERD, Clive (2000). Objects of interest. Disponível em: <http://www.fastrakconsulting.co.uk>. Acesso em: 22 mar. 2016.

SMITH, Frank. Leitura significativa. Trad. Beatriz Affonso Neves. 3. ed. Porto Alegre: Artes Médicas, 1999.

WILEY, David. Connecting learning objects to instructional design theory: a definition, a metaphor, and a taxonomy. In: WILEY, David. The instructional use of learning objects: the online version, 2000. Disponível em: <http://reusability.org>. Acesso em: 22 mar. 2016.

ZANI, Ricardo. Intertextualidade: considerações em torno do dialogismo. Em Questão: Revista da Faculdade de Biblioteconomia e Comunicação da UFRGS, Porto Alegre, v. 9, n. 1, p. 121-132, jan./jun. 2003.

Recebido em 25/04/2016

Aceito em $19 / 07 / 2016$ 